\title{
Socio-economic Correlates, Technological Gap and Training Nneeds of the Farmers for Increasing Pineapple Productivity in Meghalaya
}

\author{
J. K. Das ${ }^{1^{*}}$, Lima N. Sangma ${ }^{2}$ and D. Majumder ${ }^{3}$ \\ ${ }^{122}$ Dept. of Agricultural Extension, ${ }^{3}$ Dept. of Agricultural Statistics, Bidhan Chandra Krishi Viswavidyalaya, Mohanpur, Nadia, \\ West Bengal (741 252), India
}

\section{Corresponding Author}

J. K. Das

e-mail: jayanta1794@gmail.com

\author{
Article History \\ Article ID: AR1801b \\ Received in $28^{\text {th }}$ February, 2017 \\ Received in revised form $28^{\text {th }}$ July, 2017 \\ Accepted in $7^{\text {th }}$ August, 2017
}

\begin{abstract}
The study was conducted during 2012-13 to identify the role of different socio-economic variables on yield, income, technological gap and training need confronting the productivity of pineapple in the state of Meghalaya. Study revealed that the variable economic motivation (0.130) have recorded a positive and significant correlation with the variable income, of the respondents. The correlation coefficient between yield $\left(\mathrm{Y}_{2}\right)$ and all independent variables revealed that education of farmers (0.125), Market orientation (0.095) and cultivation efficiency (0.130) have recorded significant and positive correlation with the yield of the respondents. It is also recorded that variables Family type (-0.105), Management orientation (-0.167) and utilization of mass media (-0.137) are significant but negatively correlated with the yield of pineapple. In the path analysis, it has been found that the variable utilization of mass media has routed highest indirect effect on income as many as 16 exogenous variables. Similarly, it has also identified that both the variables management orientation and education of farmers have routed highest indirect effect on yield as many as 8 exogenous variables. The result of technological gap revealed that the highest gap (60.75\%) and the lowest gap $(30.50 \%)$ was found in the knowledge of 'sucker' and in 'post harvest technology' respectively among the pineapple growers. The farmers have shown maximum interest (rank $k^{-1}$ ) for training on 'improved cultural practices' (59.66\%) and minimum interest (rank-X) on 'cropping system' $(45.86 \%)$ in pineapple cultivation.
\end{abstract}

Keywords: Socio economic, technological gap, training needs, pineapple productivity

\section{Introduction}

BHorticulture is a growing economic powerhouse with a large economic footprint globally. It provides livelihood, employment, increased incomes, and enhanced well being and satisfaction to populations of virtually all countries. In India, horticulture has emerged as the fastest growing sector within agriculture during the last two decades. The launch of National Horticulture Mission in 2005 and the creation of Meghalaya Small Farmers Agri-business consortium is the implementing agency have resulted so many significant development in the state as a whole. Small scale growers should focus on producing pineapple for fresh market that can be sold at higher price (Raziah, 2009).

Among the major fruit crops pineapple in one of the top ranking fruit crops not only throughout the globe but in Meghalaya as well. Socio economic characteristics have been found to be influenced the productivity and income of the farmers.

Horticulture in India has emerged as the fastest growing sector within agriculture during the last two decade, triggering agricultural development. Its growth makes a direct impact on employment generation, diversification in agriculture for nutritional security and broader micro economic development of the country, which accounts for about 30\% of India's agricultural GDP from $13 \%$ of cropped area and has maintained the growth rate of more than $5 \%$ during the last two decade (AFCL, 2012). Meghalaya is ranked seventh in production of pineapples in country and contributes about $6.1 \%$ of the total production of pineapples in the country. It produces about $0.09 \mathrm{mt}$ of pineapple from an area of $0.01 \mathrm{mha}$. with productivity of $8.9 \mathrm{t} \mathrm{ha}^{-1}$ (Anonymous, 2012). As a result of adoption of improved technologies, the country has made impressive growth and the horticulture sector is poised to attain great heights. Thus the experiments were conducted to identify the extent of relationship between the different socio-economic variables (independent) on yield and income (dependent) and to assess the technological gap and training need confronting the productivity of pineapple.

\section{Materials and Methods}

The study was conducted in seven districts of Meghalaya 
viz. East Khasi Hills, West Khasi Hills, Jaintia Hills, Ri-Bhoi, West Garo Hills, East Garo Hills and South Garo Hills. The districts were selected as because in Meghalaya pineapple crop is covered under the Horticulture Mission North East and Himalayan States in almost all the existing districts. The seven districts were purposively selected for the present investigation.

There are total numbers of 39 blocks in seven districts of Meghalaya. Among these 7 blocks namely Mylliem, Mairang, Thadlaskein, Umsning, Songsak, Rongram and Rongara blocks were selected randomly for the study. The study was conducted in the year 2012-13.

There are total numbers of 346 villages in these selected seven blocks where pineapple isbeing cultivated by the farmers. Among these 346 villages, 7 villages and 200 pineapple growers were selected randomly for taking sample for this study.

There are thirty two independent $\left(\mathrm{X}_{1}-\mathrm{X}_{32}\right)$ and two dependent variables (Income $Y_{1}$, Yield $Y_{2}$ ) have been considered for the present investigation. The statistical tools used coefficient of correlation, regression analysis, and path analysis to interpret, analyze and presentation of findings.

The technological gap was calculated by using the formula:

Extent of recommendation - Extent of adoption Technological gap $=-\times 100$ Extent of recommendation

Average Choice Score (ACS) for training need was calculated by using the formula:

$A C S=\frac{(\mathrm{Cl} \times 3)+(\mathrm{Cll} \times 2)+(\mathrm{ClI} \times 1)}{3}$

Where, $\mathrm{Cl}$ is the first choice

$\mathrm{Cll}$ is the second choice

$\mathrm{CIII}$ is the third choice

\section{Results and Discussion}

In the present study various independent variables ( $X_{1}$ to $X_{32}$ ) have been correlated with dependent variables to find out whether there are significant linear relation between dependent and independent variables. This is presented in the following table.

Table 1 presents the Coefficient of correlation between Income $\left(\mathrm{Y}_{1}\right)$ and 32 independent variables for all the respondents, as figured up in the table itself.

It has been found that the variable Economic motivation $\left(\mathrm{X}_{19}\right)$ have recorded a positive and significant correlation with the variable income $\left(Y_{1}\right)$, of the respondents.

It also reveals that variables Farm size $\left(\mathrm{X}_{1}\right)$, Farm mechanization $\left(X_{3}\right)$, Education of farmers $\left(X_{10}\right)$, Farm efficiency $\left(X_{27}\right)$ and Utilization of Mass media $\left(X_{30}\right)$, are also significantly but negatively correlated with the income of the respondents.
Table 1: Correlation Coefficient between Income $\left(Y_{1}\right)$ and 32 independent variables for all respondents

Variables

Correlation coefficient $(r)$

\begin{tabular}{cc} 
& $Y_{1}$ \\
\hline Farm size $\left(X_{1}\right)$ & $-0.094^{*}$
\end{tabular}

Irrigation index $\left(X_{2}\right) \quad-0.039$

Farm mechanization $\left(X_{3}\right) \quad-0.096^{*}$

Status of land ownership $\left(X_{4}\right) \quad 0.056$

Level of adoption of new technology $\left(X_{5}\right) \quad 0.043$

Cropping intensity $\left(X_{6}\right) \quad 0.075$

Technological gap $\left(X_{7}\right) \quad-0.078$

Age $\left(X_{8}\right) \quad 0.031$

Caste of farmers $\left(X_{9}\right) \quad-0.057$

Education of farmers $\left(X_{10}\right) \quad-0.097^{*}$

Family educational status $\left(X_{11}\right) \quad-0.055$

Family type $\left(\mathrm{X}_{12}\right) \quad 0.053$

Family size $\left(X_{13}\right) \quad 0.030$

Economic status $\left(\mathrm{X}_{14}\right) \quad-0.008$

Social participation $\left(X_{15}\right) \quad 0.027$

Index of knowledge about improved pine- $\quad-0.015$

apple crop $\left(\mathrm{X}_{16}\right)$

Index of awareness about characteristics $\quad-0.017$

of pineapple crop $\left(\mathrm{X}_{17}\right)$

Risk orientation $\left(\mathrm{X}_{18}\right) \quad 0.054$

Economic motivation $\left(X_{19}\right) \quad 0.130^{*}$

Market orientation $\left(X_{20}\right) \quad-0.073$

Orientation towards competition $\left(\mathrm{X}_{21}\right) \quad 0.003$

Innovation proneness $\left(X_{22}\right) \quad 0.000$

Labour efficiency $\left(X_{23}\right) \quad-0.054$

Production efficiency $\left(X_{24}\right) \quad 0.086$

Management efficiency $\left(X_{25}\right) \quad 0.065$

Cultivation efficiency $\left(X_{26}\right) \quad-0.029$

Farm efficiency $\left(X_{27}\right) \quad-0.132^{*}$

Operational holding size $\left(\mathrm{X}_{28}\right) \quad 0.071$

Management Orientation $\left(\mathrm{X}_{29}\right) \quad 0.061$

Utilization of Mass media $\left(X_{30}\right) \quad-0.183^{* * *}$

Utilization of personal cosmopolite $\quad-0.018$ sources of information $\left(X_{31}\right)$

Utilization of personal localite sources of $\quad-0.042$ information $\left(X_{32}\right)$

\footnotetext{
${ }^{* * *}$ Significance $(p=0.01) ;{ }^{* *}$ Significance $(p=0.05)$;
}

*Significance $(p=0.10)$ 
The correlation results show that for pineapple crop growers economic motivation $\left(\mathrm{X}_{19}\right)$ has counted positively for better income. Then, it is understood that experience and learning getting off isochronously with the advancement of farmer's economic motivation, have helped the entrepreneurs to harvest higher and assured income. So it could be implied that the respondents having higher income was being unique by having higher economic motivation.

Respondents having higher income have also gone unique by retaining smaller Farm size, less Farm mechanization, lower Education of farmers, lesser Farm efficiency and less use of Mass media sources of information.

The results negative and significant correlation with the farm size and Farm mechanization proves that the variable farm size and farm mechanization have got least to play in contribution to farm enterprise management. The variable education of the farmers has also the least role to play in farm enterprise management and respondents having not that much of formal educational attainment has done better over the common farmers. Farmers having lesser farm efficiency and less use of mass media sources of information are also found to have higher income.

Sometimes few coefficients are not found to be significant as because the test statistic for such tests are depending upon the sample size. But the trend of association is also important to find out important prediction to explain the dependent variables.

Table 2 presents the Coefficient of correlation between yield $\left(\mathrm{Y}_{2}\right)$ and 32 independent variables for all the respondents.

This reveals that variable such as Education of farmers $\left(\mathrm{X}_{10}\right)$, Market orientation $\left(\mathrm{X}_{20}\right)$ and Cultivation efficiency $\left(\mathrm{X}_{26}\right)$ of the respondents have recorded significant and positive correlation with the yield $\left(\mathrm{Y}_{2}\right)$, of the respondents.

It has also been recorded that variables like Family type $\left(X_{12}\right)$, Management Orientation $\left(\mathrm{X}_{29}\right)$ and Utilization of Mass media $\left(\mathrm{X}_{30}\right)$, are significantly but negatively correlated with the yield $\left(\mathrm{Y}_{2}\right)$ of the respondents.

The results shows that the respondents having higher yield of crops are of better education, have better market orientation and more cultivation efficiency.

Education, on social alchemy of mixing between biological characters and social behaviour has gone rightly dominating on influencing the biological impact. Education is the means of socializing oneself in a given social text which perhaps, in this study have uniquely characterized the process of socializing the bio-social impact. So with the increase in formal education the respondents have assured much higher yield. The findings corroborated the study of Abdul Rahman et al. (2005).

Market is one of the important factors contributing towards farmer's better farm management. Farmer with a better knowledge about market orientation and growing more of market demand crops are assured of achieving higher and
Table 2: Correlation coefficient between yield $\left(\mathrm{Y}_{2}\right)$ and 32 independent variables for all respondents

\begin{tabular}{|c|c|}
\hline \multirow[t]{2}{*}{ Variables } & $\begin{array}{l}\text { Correlation } \\
\text { Coefficient ( } r \text { ) }\end{array}$ \\
\hline & $Y_{2}$ \\
\hline Farm size $\left(\mathrm{X}_{1}\right)$ & 0.007 \\
\hline Irrigation index $\left(X_{2}\right)$ & -0.064 \\
\hline Farm mechanization $\left(\mathrm{X}_{3}\right)$ & -0.065 \\
\hline Status of land ownership $\left(\mathrm{X}_{4}\right)$ & 0.024 \\
\hline Level of adoption of new technology $\left(X_{5}\right)$ & -0.066 \\
\hline Cropping intensity $\left(X_{6}\right)$ & 0.016 \\
\hline Technological gap $\left(\mathrm{X}_{7}\right)$ & 0.060 \\
\hline Age $\left(X_{8}\right)$ & 0.018 \\
\hline Caste of farmers $\left(\mathrm{X}_{9}\right)$ & 0.066 \\
\hline Education of farmers $\left(\mathrm{X}_{10}\right)$ & $0.125^{*}$ \\
\hline Family educational status $\left(\mathrm{X}_{11}\right)$ & 0.000 \\
\hline Family type $\left(\mathrm{X}_{12}\right)$ & $-0.105^{*}$ \\
\hline Family size $\left(\mathrm{X}_{13}\right)$ & -0.083 \\
\hline Economic status $\left(\mathrm{X}_{14}\right)$ & -0.047 \\
\hline Social participation $\left(\mathrm{X}_{15}\right)$ & -0.065 \\
\hline $\begin{array}{l}\text { Index of knowledge about improved pine- } \\
\text { apple crop }\left(X_{16}\right)\end{array}$ & 0.002 \\
\hline $\begin{array}{l}\text { Index of awareness about characteristics } \\
\text { of pineapple } \operatorname{crop}\left(\mathrm{X}_{17}\right)\end{array}$ & 0.074 \\
\hline Risk orientation $\left(\mathrm{X}_{18}\right)$ & 0.017 \\
\hline Economic motivation $\left(\mathrm{X}_{19}\right)$ & 0.031 \\
\hline Market orientation $\left(\mathrm{X}_{20}\right)$ & $0.095^{*}$ \\
\hline Orientation towards competition $\left(\mathrm{X}_{21}\right)$ & 0.054 \\
\hline Innovation proneness $\left(\mathrm{X}_{22}\right)$ & -0.039 \\
\hline Labour efficiency $\left(\mathrm{X}_{23}\right)$ & -0.032 \\
\hline Production efficiency $\left(\mathrm{X}_{24}\right)$ & -0.046 \\
\hline Management efficiency $\left(\mathrm{X}_{25}\right)$ & -0.080 \\
\hline Cultivation efficiency $\left(\mathrm{X}_{26}\right)$ & $0.130^{*}$ \\
\hline Farm efficiency $\left(\mathrm{X}_{27}\right)$ & 0.027 \\
\hline Operational holding size $\left(\mathrm{X}_{28}\right)$ & -0.043 \\
\hline Management Orientation $\left(\mathrm{X}_{29}\right)$ & $-0.167^{* *}$ \\
\hline Utilization of Mass media $\left(X_{30}\right)$ & $-0.137^{*}$ \\
\hline $\begin{array}{l}\text { Utilization of personal cosmopolite } \\
\text { sources of information }\left(X_{31}\right)\end{array}$ & 0.001 \\
\hline $\begin{array}{l}\text { Utilization of personal localite sources of } \\
\text { information }\left(\mathrm{X}_{32}\right)\end{array}$ & -0.024 \\
\hline
\end{tabular}

${ }^{* * *}$ Significance $(p=0.01) ;{ }^{* *}$ Significance $(p=0.05)$;

*Significance $(p=0.10)$ 
greater yield. Efficiency of crop production and the level of profit from the pineapple crop cultivation to great extent depend upon the cultivation efficiency of the farmer's practices. If managed properly the crop can yield the rich dividends. Also the respondents with higher cultivation efficiency are characterized by the increase in the yield of crops.

It is also discernible that the respondents with higher yield of crops are having small family type, lower management orientation and fewer tunes to utilization of mass media sources of information.

\subsection{Regression}

Step down multiple regressions helps us to screen out the significant variables from relatively trivial ones.

Step down method is one variable selection technique multiple regression where only significant predictors are selected discarding other predictions which are sharing high linear association with selected predictor (s). Only best fitted model of step down technique is displayed.

Table 3: Step down regression: Causal or predictor variables on Income $\left(Y_{1}\right)$, the consequent variable

\begin{tabular}{|c|c|c|c|c|c|}
\hline \multirow[t]{2}{*}{$\begin{array}{l}\text { Varia } \\
\text { ble }\end{array}$} & \multicolumn{2}{|c|}{$\begin{array}{l}\text { Unstandardized } \\
\text { Coefficients }\end{array}$} & \multirow{2}{*}{$\begin{array}{c}\text { Standar } \\
\text { dized } \\
\text { coeffi } \\
\text { cients } \\
\text { Beta }\end{array}$} & \multirow[t]{2}{*}{$\mathrm{t}$} & \multirow[t]{2}{*}{ Sig. } \\
\hline & B & $\begin{array}{l}\text { Std. } \\
\text { Error }\end{array}$ & & & \\
\hline $\begin{array}{l}\text { (Const } \\
\text { ant) }\end{array}$ & 4078.301 & 198.253 & & 20.571 & 0.000 \\
\hline $\begin{array}{l}\text { Utiliza } \\
\text { tion of } \\
\text { mass } \\
\text { media } \\
\left(X_{30}\right)\end{array}$ & -475.602 & 182.089 & -0.183 & $\underset{* * *}{-2.612}$ & 0.010 \\
\hline $\mathrm{R}$ & R Square & $\begin{array}{c}\text { Adjus } \\
\text { ted R } \\
\text { Square }\end{array}$ & $\begin{array}{l}\text { Std. Error } \\
\text { of the } \\
\text { Estimate }\end{array}$ & & \\
\hline 0.183 & 0.033 & 0.029 & 1033.449 & & \\
\hline
\end{tabular}

${ }^{* * *}$ denotes significant at $(p=0.01)$

Table 3 presents the result of step down multiple regression analysis of income $\left(\mathrm{Y}_{1}\right)$ with independent variables.

The step down analysis has isolated one critical causal variable i.e. utilization of mass media $\left(X_{30}\right)$ as the only predictor to have an impact on income. The variable has explained $3.3 \%$ of variance embedded with consequent variable. It can be concluded from the table that use of mass media source of information have a substantive impact on the income of the farmers in their farming community.

The remaining variable under study could not emerge as significant predictors as indicated from the non significant ' $t$ ' value in all the cases.

Table 4: Step down regression: Causal or predictor variables on Yield $\left(\mathrm{Y}_{2}\right)$, the consequent variable

\begin{tabular}{lccccc}
\hline $\begin{array}{l}\text { Vari- } \\
\text { able }\end{array}$ & \multicolumn{2}{c}{$\begin{array}{c}\text { Unstandardized } \\
\text { Coefficients }\end{array}$} & SC & t & Sig. \\
\hline \multicolumn{7}{c}{ B } & $\begin{array}{c}\text { Std. Er- } \\
\text { ror }\end{array}$ & Beta & 3.371 & 0.001 \\
$\begin{array}{l}\text { (Con- } \\
\text { stant) }\end{array}$ & 88544.334 & 26264.72 & & $-2.391^{* *}$ & 0.018 \\
MR & 16863.310 & 7052.862 & -0.165 & $-2.485^{* *}$ & 0.014 \\
UMM & -9082.238 & 3655.494 & -0.176 & $2.287^{* *}$ & 0.023 \\
& 3149.065 & 1376.904 & 0.162 & & \\
R & R Square & Adjusted & SEE & & \\
& & R Square & & & \\
0.268 & 0.072 & 0.058 & 20171.964 & & \\
\hline
\end{tabular}

SC: Standardized coefficients; MR: Management orientation (X29); UMM: Utilization of mass media (X30); EF: Education of farmers (X10); SEE: Std. Error of the Estimate; ${ }^{* *}$ denotes significant at $5 \%$ level of significance

Table 4 presents the result of step down multiple regression analysis of yield $\left(\mathrm{Y}_{2}\right)$ with independent variables. The step down regression analysis has isolated at the last step three critical causal variables, namely management orientation $\left(X_{29}\right)$, utilization of mass media $\left(X_{30}\right)$ and education of farmers $\left(X_{10}\right)$ as the predictors to have substantive impact on yield. The three variables altogether have explained $7.2 \%$ of variance embedded with consequent variable.

The profiling of knowledge in any crop cultivation can well be predicted by the indicators like management orientation, utilization of mass media and education of farmers. These three characters being a character of a social esteem have still been dominant predictors of the cognitive status of the farmers on any crop cultivation practices per se.

The three variables namely, management orientation $\left(X_{29}\right)$, utilization of mass media $\left(X_{30}\right)$ and Education of farmers $\left(X_{10}\right)$ together have contributed $7.2 \%$ variance in the consequent variable Yield $\left(\mathrm{Y}_{2}\right)$ respectively, emerged as significantly contributors towards the training need and have a definite role in affecting the training need perception of the farmers. These variables deserved to be looked into while planning any training strategy for all the farmers with respect to pineapple and other major crop cultivation. The remaining variable under study could not emerged as significant predictors as indicated from the non significant ' $\mathrm{t}$ ' value in all the cases.

\subsection{Path analysis}

Table 5 presents the path analysis to depict the total effect, total direct effect, total indirect effect and highest indirect effect of the exogenous variables on consequent variable 
income $\left(Y_{1}\right)$. It has been found that the variable utilization of mass media $\left(X_{30}\right)$ has exerted the highest total effect with negative value on income $\left(Y_{1}\right)$, while the same variable also has exerted highest direct effect on it.

It is also to note that the variable utilization of mass media $\left(X_{30}\right)$ has highest indirect effect on income as many as 16 exogenous variables associated with the variable income. Another variable social participation $\left(\mathrm{X}_{15}\right)$ has exerted highest positive total indirect effect on consequent variable income $\left(Y_{1}\right)$.

Table 6 shows the path analysis to explain the total effect, total direct effect, total indirect effect and highest indirect effect on the exogenous variable yield $\left(\mathrm{Y}_{2}\right)$. It is reflected that

Table 5: Income $\left(Y_{1}\right)$ vs. exogenous variables $\left(X_{1}\right.$ to $\left.X_{32}\right)$

\begin{tabular}{|c|c|c|c|c|}
\hline Variables & $\begin{array}{l}\text { Total } \\
\text { effect }(r)\end{array}$ & $\begin{array}{l}\text { Total direct } \\
\text { effect (TDE) }\end{array}$ & $\begin{array}{l}\text { Total indirect } \\
\text { effect (TIE) }\end{array}$ & $\begin{array}{l}\text { Highest indirect } \\
\text { effect through X }\end{array}$ \\
\hline Farm size $\left(X_{1}\right)$ & -0.094 & -0.105 & 0.011 & $0.009\left(X_{7}\right)$ \\
\hline Irrigation index $\left(X_{2}\right)$ & -0.039 & -0.078 & 0.039 & $0.017\left(X_{30}\right)$ \\
\hline Farm mechanization $\left(\mathrm{X}_{3}\right)$ & -0.096 & -0.061 & 0.035 & $0.015\left(X_{32}\right)$ \\
\hline Status of land ownership $\left(\mathrm{X}_{4}\right)$ & 0.056 & 0.038 & 0.018 & $0.017\left(X_{18}\right)$ \\
\hline Level of adoption of new technology $\left(X_{5}\right)$ & 0.043 & 0.049 & 0.006 & $-0.017\left(X_{28}\right)$ \\
\hline Cropping intensity $\left(\mathrm{X}_{6}\right)$ & 0.075 & 0.073 & 0.002 & $-0.028\left(X_{30}\right)$ \\
\hline Technological gap $\left(X_{7}\right)$ & -0.078 & -0.124 & 0.046 & $0.027\left(X_{30}\right)$ \\
\hline Age $\left(X_{8}\right)$ & 0.031 & 0.085 & 0.054 & $-0.024\left(X_{30}\right)$ \\
\hline Caste $\left(X_{9}\right)$ & -0.057 & -0.102 & 0.045 & $0.027\left(X_{30}\right)$ \\
\hline Education of farmers $\left(\mathrm{X}_{10}\right)$ & -0.097 & -0.106 & 0.009 & $-0.057\left(X_{30}\right)$ \\
\hline Family educational status $\left(\mathrm{X}_{11}\right)$ & -0.055 & -0.118 & 0.063 & $0.017\left(X_{30}\right)$ \\
\hline Family type $\left(\mathrm{X}_{12}\right)$ & 0.053 & 0.013 & 0.04 & $-0.029\left(X_{30}\right)$ \\
\hline Family size $\left(\mathrm{X}_{13}\right)$ & 0.030 & -0.025 & -0.005 & $-0.017\left(X_{30}\right)$ \\
\hline Economic status $\left(\mathrm{X}_{14}\right)$ & -0.008 & -0.042 & 0.034 & $0.014\left(X_{32}\right)$ \\
\hline Social participation $\left(\mathrm{X}_{15}\right)$ & 0.027 & 0.107 & 0.08 & $-0.020\left(X_{19}\right)$ \\
\hline $\begin{array}{l}\text { Index of knowledge about improved pineapple and other } \\
\text { major crop }\left(X_{16}\right)\end{array}$ & -0.015 & -0.027 & 0.012 & $0.013\left(X_{7}\right)$ \\
\hline $\begin{array}{l}\text { Index of awareness about characteristics of pineapple and } \\
\text { other major crops }\left(X_{17}\right)\end{array}$ & -0.017 & -0.014 & 0.003 & $0.013\left(X_{30}\right)$ \\
\hline Risk orientation $\left(\mathrm{X}_{18}\right)$ & 0.054 & 0.105 & 0.051 & $-0.019\left(X_{7}\right)$ \\
\hline Economic motivation $\left(\mathrm{X}_{19}\right)$ & 0.130 & 0.142 & 0.012 & $-0.015\left(X_{15}\right)$ \\
\hline Market orientation $\left(\mathrm{X}_{20}\right)$ & -0.073 & -0.083 & 0.01 & $-0.015\left(X_{7}\right)$ \\
\hline Orientation towards competition $\left(\mathrm{X}_{21}\right)$ & 0.003 & -0.023 & -0.02 & $0.017\left(X_{30}\right)$ \\
\hline Innovation proneness $\left(\mathrm{X}_{22}\right)$ & 0.000 & -0.034 & -0.034 & $-0.017\left(X_{19}\right)$ \\
\hline Labour efficiency $\left(\mathrm{X}_{23}\right)$ & -0.054 & -0.065 & 0.011 & $0.009\left(X_{11}\right)$ \\
\hline Production efficiency $\left(\mathrm{X}_{24}\right)$ & 0.086 & 0.058 & 0.028 & $-0.024\left(X_{11}\right)$ \\
\hline Management efficiency $\left(X_{25}\right)$ & 0.065 & 0.078 & 0.013 & $0.015\left(X_{30}\right)$ \\
\hline Cultivation efficiency $\left(\mathrm{X}_{26}\right)$ & -0.029 & -0.036 & 0.007 & $0.013\left(X_{1}\right)$ \\
\hline Farm efficiency $\left(X_{27}\right)$ & -0.132 & -0.112 & 0.02 & $-0.009\left(X_{30}\right)$ \\
\hline Operational holding size $\left(\mathrm{X}_{28}\right)$ & 0.071 & 0.118 & 0.047 & $-0.041\left(X_{30}\right)$ \\
\hline Management orientation $\left(\mathrm{X}_{29}\right)$ & 0.061 & 0.029 & 0.032 & $0.019\left(X_{28}\right)$ \\
\hline Utilization of mass media $\left(X_{30}\right)$ & -0.183 & -0.243 & 0.06 & $-0.025\left(X_{10}\right)$ \\
\hline Utilization of personal cosmopolite sources of information $\left(X_{31}\right)$ & -0.018 & 0.004 & -0.014 & $0.014\left(X_{30}\right)$ \\
\hline Utilization of personal localite sources of information. $\left(\mathrm{X}_{32}\right)$ & -0.042 & -0.091 & 0.049 & $0.014\left(X_{30}\right)$ \\
\hline
\end{tabular}


the variable management orientation $\left(X_{29}\right)$ has exerted the highest total effect with the negative value on yield $\left(Y_{2}\right)$,the same variable has also the highest direct effect on it.

The result also reveals that both the variables education of the farmers $\left(X_{10}\right)$ and management orientation $\left(X_{29}\right)$ has routed highest indirect effect on yield as many as 8 exogenous variables characterize the variable yield $\left(\mathrm{Y}_{2}\right)$.

Another variable family size $\left(X_{13}\right)$ has influence the highest indirect effect on the consequent variable yield $\left(Y_{2}\right)$.

3.3. Extent of technological gap in pineapple cultivation

\begin{tabular}{|c|c|c|c|c|}
\hline Variables & $\begin{array}{l}\text { Total effect } \\
(r)\end{array}$ & $\begin{array}{l}\text { Total direct effect } \\
\text { (TDE) }\end{array}$ & $\begin{array}{l}\text { Total indirect effect } \\
\text { (TIE) }\end{array}$ & $\begin{array}{l}\text { Highest indirect effect } \\
\text { through } X\end{array}$ \\
\hline Farm size $\left(\mathrm{X}_{1}\right)$ & 0.007 & 0.034 & 0.027 & $-0.016\left(X_{26}\right)$ \\
\hline Irrigation index $\left(\mathrm{X}_{2}\right)$ & -0.064 & -0.031 & 0.033 & $-0.019\left(X_{10}\right)$ \\
\hline Farm mechanization $\left(\mathrm{X}_{3}\right)$ & -0.065 & -0.078 & 0.013 & $0.010\left(x_{32}\right)$ \\
\hline Status of land ownership $\left(\mathrm{X}_{4}\right)$ & 0.024 & 0.007 & 0.017 & $0.013\left(x_{10}\right)$ \\
\hline Level of adoption of new technology $\left(X_{5}\right)$ & -0.066 & -0.035 & 0.031 & $-0.013\left(X_{26}\right)$ \\
\hline Cropping intensity $\left(\mathrm{X}_{6}\right)$ & 0.016 & 0.061 & 0.045 & $-0.022\left(X_{29}\right)$ \\
\hline Technological gap $\left(X_{7}\right)$ & 0.060 & 0.086 & 0.026 & $-0.019\left(X_{10}\right)$ \\
\hline Age $\left(X_{8}\right)$ & 0.018 & 0.016 & 0.002 & $0.017\left(x_{10}\right)$ \\
\hline Caste $\left(\mathrm{X}_{9}\right)$ & 0.066 & 0.026 & 0.04 & $0.020\left(X_{10}\right)$ \\
\hline Education of farmers $\left(\mathrm{X}_{10}\right)$ & 0.125 & 0.133 & 0.008 & $-0.036\left(X_{30}\right)$ \\
\hline Family educational status $\left(\mathrm{X}_{11}\right)$ & 0.000 & 0.013 & 0.013 & $-0.020\left(X_{29}\right)$ \\
\hline Family type $\left(\mathrm{X}_{12}\right)$ & -0.105 & -0.098 & 0.007 & $-0.018\left(X_{30}\right)$ \\
\hline Family size $\left(\mathrm{X}_{13}\right)$ & -0.083 & -0.010 & 0.073 & $-0.048\left(X_{12}\right)$ \\
\hline Economic status $\left(\mathrm{X}_{14}\right)$ & -0.047 & -0.043 & 0.004 & $0.010\left(X_{26}\right)$ \\
\hline Social participation $\left(\mathrm{X}_{15}\right)$ & -0.065 & -0.081 & 0.016 & $0.009\left(X_{7}\right)$ \\
\hline $\begin{array}{l}\text { Index of knowledge about improved } \\
\text { pineapple crop }\left(\mathrm{X}_{16}\right)\end{array}$ & 0.002 & -0.002 & -0 & $-0.012\left(X_{29}\right)$ \\
\hline $\begin{array}{l}\text { Index of awareness about characteris- } \\
\text { tics of pineapple } \operatorname{crop}\left(\mathrm{X}_{17}\right)\end{array}$ & 0.074 & 0.033 & 0.041 & $0.030\left(X_{29}\right)$ \\
\hline Risk orientation $\left(\mathrm{X}_{18}\right)$ & 0.017 & -0.020 & -0.003 & $0.013\left(X_{7}\right)$ \\
\hline Economic motivation $\left(\mathrm{X}_{19}\right)$ & 0.031 & 0.005 & 0.026 & $0.014\left(X_{10}\right)$ \\
\hline Market orientation $\left(\mathrm{X}_{20}\right)$ & 0.095 & 0.069 & 0.026 & $0.010\left(X_{12}\right)$ \\
\hline Orientation towards competition $\left(\mathrm{X}_{21}\right)$ & 0.054 & 0.028 & 0.026 & $0.011\left(x_{30}\right)$ \\
\hline Innovation proneness $\left(\mathrm{X}_{22}\right)$ & -0.039 & -0.009 & 0.03 & $-0.018\left(X_{10}\right)$ \\
\hline Labour efficiency $\left(\mathrm{X}_{23}\right)$ & -0.032 & -0.041 & 0.009 & $-0.008\left(X_{20}\right)$ \\
\hline Production efficiency $\left(\mathrm{X}_{24}\right)$ & -0.046 & 0.011 & 0.035 & $-0.019\left(X_{29}\right)$ \\
\hline Management efficiency $\left(X_{25}\right)$ & -0.080 & -0.074 & 0.006 & $-0.017\left(X_{29}\right)$ \\
\hline Cultivation efficiency $\left(\mathrm{X}_{26}\right)$ & 0.130 & 0.129 & 0.001 & $0.017\left(X_{29}\right)$ \\
\hline Farm efficiency $\left(\mathrm{X}_{27}\right)$ & 0.027 & 0.033 & 0.006 & $0.013\left(X_{26}\right)$ \\
\hline Operational holding size $\left(\mathrm{X}_{28}\right)$ & -0.043 & 0.005 & -0.038 & $-0.026\left(X_{29}\right)$ \\
\hline Management orientation $\left(\mathrm{X}_{29}\right)$ & -0.167 & -0.161 & 0.006 & $-0.013\left(X_{26}\right)$ \\
\hline Utilization of mass media $\left(\mathrm{X}_{30}\right)$ & -0.137 & -0.152 & 0.015 & $0.031\left(X_{10}\right)$ \\
\hline $\begin{array}{l}\text { Utilization of personal cosmopolite } \\
\text { sources of information }\left(X_{31}\right)\end{array}$ & 0.001 & 0.007 & 0.006 & $0.009\left(X_{30}\right)$ \\
\hline $\begin{array}{l}\text { Utilization of personal localite sources } \\
\text { of information. }\left(X_{32}\right)\end{array}$ & -0.024 & -0.060 & 0.036 & $0.012\left(X_{3}\right)$ \\
\hline
\end{tabular}


Improved pineapple production technologies in the form of package of practices are developed by the scientists and recommended to the farming community for adoption. The objective is to increase the production and productivity of the crop. In spite of numerous and concerted efforts of agricultural scientists, there still exists a wide gap between the recommended technologies and the adoption of these technologies in the field by the farmers.

Therefore, it is necessary to reduce the technological gap in the field of pineapple growing farmers of Meghalaya and other producing states for increasing the crop yields at desired level.

The results of technological gap (Table 7 ) revealed that the farmers in general were not fully aware about the latest production technology. The findings indicated that for all the farmers, technological gap with respect to pineapple cultivation range from 30.50 to $60.75 \%$. The highest gap $(60.75 \%)$ was found in the knowledge of "sucker". This gap clearly indicates the low adoption of improved varieties of pineapple might be due to the fact that farmers are normally unaware about newly recommended varieties of pineapple well suited to the environment. As known, selection of suitable high yielding variety for a given agro-climatic situation is the

Table 7: Extent of technological gap of farmers in pineapple cultivation

\begin{tabular}{|c|c|c|c|c|c|}
\hline SI. No. & $\begin{array}{c}\text { Prac- } \\
\text { tices of } \\
\text { Pineapple } \\
\text { cultivation }\end{array}$ & $\begin{array}{l}\text { Maxi- } \\
\text { mum at- } \\
\text { tainable } \\
\text { scores }\end{array}$ & $\begin{array}{c}\text { Mean } \\
\text { scores } \\
\text { ob- } \\
\text { tained }\end{array}$ & $\begin{array}{l}\text { Gap } \\
\text { in } \\
\text { score }\end{array}$ & $\begin{array}{c}\text { Ran- } \\
\text { ks }\end{array}$ \\
\hline 1. Sucker & 14 & 5.50 & 8.50 & 60.75 & 1 \\
\hline $\begin{array}{l}\text { 2. Sowing } \\
\text { methods }\end{array}$ & 6 & 3.15 & 2.68 & 47.58 & IV \\
\hline $\begin{array}{l}\text { 3. Fertiliz- } \\
\text { er applica- } \\
\text { tion }\end{array}$ & 24 & 10.40 & 13.60 & 56.67 & II \\
\hline $\begin{array}{l}\text { 4. Irriga- } \\
\text { tion }\end{array}$ & 6 & 3.21 & 2.80 & 46.58 & V \\
\hline $\begin{array}{l}\text { 5. Weed } \\
\text { control }\end{array}$ & 21 & 10.74 & 10.26 & 48.86 & III \\
\hline $\begin{array}{l}\text { 6. Pest } \\
\text { control }\end{array}$ & 16 & 9.74 & 6.27 & 39.16 & VI \\
\hline $\begin{array}{l}\text { 7. Post } \\
\text { harvest } \\
\text { technology }\end{array}$ & 4 & 2.78 & 1.22 & 30.50 & VII \\
\hline
\end{tabular}

crucial need.

The second major technological gap of $56.67 \%$ was noticed in the practice of fertilizer application. This might be due to inadequate knowledge about balanced nutrition and critical phases of nutrient requirement as per production recommendation. Majority of the farmers were particularly applying blanket dose of easily available and less costly nitrogenous fertilizers. The lowest technological gap of 30.50 per cent was found in post-harvest technology practice among the pineapple growers. This might be due to awareness of farmers about the safe storage and handling of pineapple crop. The reason is obvious as the farmers are using mechanical methods of pineapple storage.

Table 8 reveals that the farmers have shown more interest for training in improved cultural practices and accorded it as the most preferred area of training. It is interesting that the farmers have also shown their interest for training in use of H.Y.Vs (Singh and Singh, 1982) and Integrated Nutrient Management (INM) (Dharnal, 2011) and accorded it as $2^{\text {nd }}$ and $3^{\text {rd }}$ rank respectively in order of priority. The component Water Management and Integrated Pest and Disease Management (Sajeev and Singh, 2010) have been given ranks at $4^{\text {th }}$ and $5^{\text {th }}$ position respectively. Post-Harvest Technology (Dharrnal,

Table 8: Perception of training need of farmers in the main areas of pineapple production

\begin{tabular}{|c|c|c|c|}
\hline \multirow[t]{2}{*}{$\begin{array}{l}\text { Sl. } \\
\text { No. }\end{array}$} & \multirow[t]{2}{*}{ Main area of training } & \multicolumn{2}{|c|}{$\begin{array}{l}\text { Total no. of respon- } \\
\text { dents }(\mathrm{N}=200)\end{array}$} \\
\hline & & ACS & Rank \\
\hline 1. & Land preparation & 50.69 & VII \\
\hline 2. & Use of HYVs & 58.44 & II \\
\hline 3. & Sucker treatment & 50.55 & VIII \\
\hline 4. & Improved cultural practices & 59.66 & I \\
\hline 5. & $\begin{array}{l}\text { Integrated nutrient man- } \\
\text { agement (INM) }\end{array}$ & 56.62 & III \\
\hline 6. & Weed management & 46.12 & IX \\
\hline 7. & Cropping system & 45.86 & $\mathrm{X}$ \\
\hline 8. & $\begin{array}{l}\text { Integrated pest and dis- } \\
\text { ease management (IPM) }\end{array}$ & 54.32 & V \\
\hline 9. & Water management & 56.20 & IV \\
\hline $\begin{array}{l}10 . \\
\text { (ACS }\end{array}$ & $\begin{aligned} & \text { Post harvest technology } \\
= & \text { Average Choice Score) }\end{aligned}$ & 52.85 & VI \\
\hline
\end{tabular}

2011), Land preparation and Sucker treatment have been ranked at $6^{\text {th }}, 7^{\text {th }}$ and $8^{\text {th }}$ position respectively in training priority by the farmers. It is clear from the table that Weed Management and Cropping system were accorded the last of the two choices in training priority area by the farmers.

\section{Conclusion}

The income and yield from pineapple enterprise are favoring by the factors of cultivation efficiency, economic motivation, education and market orientation of the farmers in Meghalaya. Besides, utilization of mass media and management orientation helped to reap the benefit of the harvested 
produce to a great extent. Social participation and family size are also playing a significant role in augmenting the yield and income from the pineapple cultivation.

\section{References}

Abdul Rahman, S., Mohammad Isa, M., Mohammad Zulfikar, K., 2005. Factors affecting the Performance of Pineapple Smallholders in Kampun Meranek. Research Project. Universiti Teknologi Mara Sarawak.

Agricultural Finance Corporation Limited, 2012. Impact Evaluation Report of Horticulture Mission for North East and Himalayan States (HMNEH), Performance during XI plan 2007-08 to 2011-12.

Dharnal, R., 2011. Training need assessment of farmers to improve the productivity of ginger in some selected areas of Darjeeling district. Unpublished Ph.D thesis. Dept. of Agricultural Extension, B.C.K.V., West Bengal.

Raziah, M.Z., 2009. Scenario and prospect of Malaysia's pineapple industry. Economic and Technology Management Review Vol. 4

Sanjeev, M.V., Singh, A.K., 2010. Capacity building through KVKs: training needs analysis of farmers of Arunachal Pradesh. Indian Research Journal of Extension Education 10(1), Umiam, Meghalaya.

Singh, A., Singh, S., 1982. Training needs of tribal farmers. Indian Journal of Extension Education 17(3\&4), 81-88.

State wise Horticulture Status, 2012. Horticulture Statistics Division Department of Agriculture, Cooperation \& Farmers Welfare Ministry of Agriculture \& Farmers Welfare Government of India. 